\title{
HUBUNGAN KARAKTERISTIK INTERNAL PETANI DENGAN KEBERHASILAN PERTUMBUHAN CEMPAKA (Michelia champaca L.) DI DEMPLOT HUTAN RAKYAT
}

\author{
Correlation Between Internal Characteristics of Farmer with The Success of Cempaka \\ Growth (Michelia champaca L.) on Private Forest Demonstration Plot
}

\author{
Irma Yeny, Murniati dan/and Dona Octavia \\ Pusat Penelitian dan Pengembangan Hutan \\ Jl. Gunung Batu No. 5 Po Box 165 Bogor, Jawa Barat, Indonesia \\ Telp. 0251-8633234; Fax 0251-8638111 \\ E-mail: irmayeny.kemenhut@yahoo.com; murniati@forda-mof.org; donasyifa@gmail.com
}

Tanggal diterima: 23 Maret 2017; Tanggal direvisi: 30 Mei 2017; Tanggal disetujui: 22 Juni 2017

\begin{abstract}
Most of the establishment of community forests fail due to lack of understanding about the characteristics of farmers. Effort to conserve cempaka (Michelia champaca L.) could be done through development of cempaka private forest. This research aimed to study correlation between internal characteristics of farmers (knowledge, attitude and behavior) with growth performance of cempaka on a private forest demonstration plot. Cempaka private forest was established in two phases (2012 and 2013), involved 36 farmers. Data was collected by structured interview with farmers and measurement of cempaka growth. Data were analyzed using Pearson Correlation Test. The result showed that there was a significant correlation between internal characteristics of farmers with growth performance of cempaka. Positive correlation was shown between attitude and behavior with the successfull of cempaka growth. The strongest correlation was shown by behavioral characteristic, as high growth performance of cempaka was strongly influenced by farmer's activity in plant maintenance. Distinctive farmer characteristics require different approaches farmers empowerment. Training in cultivation technique and economical aspect of cempaka should be provided to farmer with characeristics: good knowledge, good attitude, fair behavior. In contrary, land optimalization and strengthening farmers' institution to anticipate larger timber market should be conducted to farmer with characteristics: poor knowledge, good attitude, good behavior. This results could be applied for farmer empowerment at Ginanjar Village in the future.
\end{abstract}

Keywords: Correlation, farmer characteristics, growth, Michelia champaca, private forest

\begin{abstract}
ABSTRAK
Pembangunan hutan rakyat sering mengalami kegagalan akibat kurangnya pemahaman tentang karakteritik kehidupan petani. Salah satu upaya melestarikan cempaka (Michelia champaca L.) dapat dilakukan dengan pola hutan rakyat. Tujuan penelitian adalah untuk mempelajari hubungan antara karakteristik internal petani (pengetahuan, sikap dan perilaku) dengan keberhasilan tumbuh cempaka. Pembangunan hutan rakyat cempaka dilakukan dua fase yaitu 2012 dan 2013, dengan melibatkan total 36 petani. Penelitian dilakukan melalui wawancara terstruktur responden (petani) dan pengukuran pertumbuhan tanaman cempaka. Analisis dilakukan dengan uji korelasi Pearson. Hasil penelitian menunjukkan terdapat hubungan yang nyata antara karakteristik internal petani (pengetahuan, sikap dan perilaku) dengan keberhasilan tumbuh cempaka. Hubungan positif ditunjukkan oleh sikap dan perilaku, dimana semakin baik sikap dan perilaku, maka semakin tinggi keberhasilan tumbuh cempaka. Hubungan yang paling kuat ditunjukkan oleh karakteristik perilaku, dimana keberhasilan pertumbuhan cempaka sangat dipengaruhi oleh aktifitas petani dalam pemeliharaan tanaman. Perbedaan hubungan karakteristik petani terhadap keberhasilan tumbuh cempaka membutuhkan pembinaan yang berbeda untuk meningkatkan keberhasilan penanaman. Pembinaan petani dengan karakteristik pengetahuan baik, sikap baik dan perilaku sedang dapat dilakukan dengan meningkatkan pengetahuan teknik budidaya dan keekonomian cempaka. Sebaliknya pembinaan petani dengan karakteristik pengetahuan kurang, sikap baik dan perilaku baik dapat dilakukan dengan optimalisasi lahan dan penguatan kelembagaan petani. Hasil penelitian ini selanjutnya dapat menjadi acuan pembinaan petani cempaka di Desa Ginanjar pada masa datang.
\end{abstract}

Kata Kunci : Cempaka, hutan rakyat, karakteristik petani, korelasi, pertumbuhan 


\section{PENDAHULUAN}

Karakteristik internal petani merupakan gambaran awal kemampuan petani dalam mengelola usahatani secara lebih baik dan berkesinambungan. Karakteristik internal petani meliputi pengetahuan, sikap dan perilaku petani. Pengetahuan merupakan berbagai gejala yang ditemui dan diperoleh manusia melalui pengamatan panca indera. Terdapat enam tingkatan di dalam domain pengetahuan yaitu: 1) tahu (know), 2) memahami (comprehension), 3) aplikasi (application), 4) analisis (analysis), 5) sintesis (synthesis), 6) evaluasi (evaluation) (Wawan \& Dewi, 2011). Sikap merupakan keyakinan dan perasaan yang melekat tentang obyek tertentu dan kecenderungan untuk bertindak terhadap obyek tersebut dengan cara tertentu. Perilaku merupakan respon indvidu terhadap suatu stimulus atau suatu tindakan yang dapat diamati dan mempunyai tujuan, baik disadari maupun tidak disadari (Wawan \& Dewi, 2011).

Pertumbuhan awal tanaman merupakan periode kritis yang sangat menentukan keberhasilan pertumbuhan pada tahap pembibitan maupun di lapangan. Pertumbuhan awal bibit ditentukan oleh faktor internal (genetik) dan faktor lingkungan. Faktor genetik adalah faktor tanaman itu sendiri, yaitu sifat yang terdapat di dalam bahan tanam/benih yang digunakan dalam budidaya tanaman. Faktor lingkungan yaitu sesuatu yang ada di sekeliling tanaman. Beberapa ilmuwan mengelompokkan faktor lingkungan menjadi dua kelompok, yaitu kelompok abiotik (iklim, tanah) dan kelompok biotik (makluk hidup) yaitu biotis (tanaman dan hewan) dan anthrofis (manusia). Faktor lingkungan meliputi media tanam dan ketersediaan cadangan makanan pada bibit (Yulianingtyas, Sebayang, \& Tyasmoro, 2015). Faktor manusia terlihat pada interaksi manusia dengan tanaman. Interaksi tersebut ditunjukkan dalam aktivitas pemeliharaan yang diduga berhubungan dengan karakteristik internal petani. Hubungan tersebut akan diuji melalui interaksi petani hutan rakyat terhadap jenis tanaman cempaka.

Cempaka (Michelia cempaka L.) termasuk famili Magnoliaceae memiliki wilayah sebaran di Indonesia meliputi Sumatera, Jawa, Sulawesi dan Kepulauan Sunda Kecil. Di Indonesia jenis ini memiliki beberapa nama daerah seperti campaka giraji, cempaka, campaga, campaka, jeumpa, dan campaka koneng. Di Sumatera Selatan, pohon M. champaca dikenal dengan nama daerah bambang lanang atau medang bambang. Cempaka merupakan tanaman dengan multi fungsi. Kayunya dapat dimanfaatkan sebagai bahan baku industri plywood, particle board, vinir, ukiran, konstruksi dan furnitur. Sementara bunganya yang mengeluarkan aroma wangi merupakan bahan baku minyak atsiri. Banyaknya manfaat yang dimiliki tanaman cempaka serta semakin rendahnya populasi di alam menjadi alasan penting untuk meningkatkan populasi melalui budidaya, khususnya di lahan milik petani dalam bentuk hutan rakyat.

Undang-undang No. 41 tahun 1999 tentang Kehutanan meyebutkan hutan rakyat adalah hutan yang tumbuh di atas lahan yang dibebani hak milik. Lebih lanjut dalam Permenhut No. P.9/MenhutII/2013, hutan rakyat didefinisikan sebagai hutan yang tumbuh di atas tanah yang dibebani hak milik atau hak lainnya di luar kawasan hutan dengan ketentuan luas minimal 0,25 ha, penutupan tajuk tanaman kayu-kayuan dan tanaman lainnya lebih dari 50\%. Dewasa ini hutan rakyat tumbuh dan berkembang di Pulau Jawa. Di Jawa Barat, khususnya di Kabupaten Sukabumi luas hutan rakyat mengalami peningkatan sampai dengan tahun 2007 dan menurun pada tahun berikutnya. Luas hutan rakyat tiap tahunnya yaitu: 39.283 ha (2005), 39.617 ha (2006), 39.303 ha (2007), 34.917 ha (2008), 30.245 ha (2009) dan 30.245 ha 
(2010). Penurunan luas hutan rakyat paling besar pada tahun 2009, yaitu 4.672 ha dari tahun sebelumnya. Penurunan luas hutan rakyat di Kabupaten Sukabumi dipengaruhi oleh pengelolaan hutan rakyat yang tidak intensif (Fahmi, Winandi, \& Kusnandi, 2013).

Penurunan luas tanaman hutan rakyat mengakibatkan penurunan produksi kayu dari hutan rakyat di Kabupaten Sukabumi. Produksi tertinggi di tahun 2007 sebesar $85.036 \mathrm{~m}^{3}$ dan menurun menjadi $37.404 \mathrm{~m}^{3}$ pada tahun 2009. Winata \& Yuliana (2014) menyebutkan bahwa jumlah jenis pohon yang dikelola secara intensif dan dominan memiliki kecenderungan produktivitas yang tinggi. Oleh karena itu, pemilihan jenis pada hutan rakyat menjadi pertimbangan pertama keberhasilan hutan rakyat. Terdapat tiga kriteria yang sering menjadi pertimbangan petani dalam menentukan jenis yaitu : 1) karakteristik jenis sesuai dengan lahan yang tersedia, 2) memiliki umur panen yang pendek, 3) mudah dipasarkan. Berdasarkan kriteria tersebut, maka pengenalan sifat tanaman cempaka dan teknik budidaya diberikan kepada petani hutan rakyat di Desa Ginanjar, Kecamatan Ciambar, Kabupaten Sukabumi melalui kegiatan sosialisasi. Proses sosialisasi jenis cempaka dilakukan dengan pendekatan sosiologis yaitu dengan teknik diskusi secara mendalam terhadap kelompok dan pengamatan langsung terhadap individu petani terkait kebiasaan berusaha tani dan pengetahuan tanaman cempaka.

Pendekatan ini menjadi dasar untuk mengetahui sejahumana petani memiliki respon yang baik terhadap pengembangan cempaka. Berdasarkan respon tersebut, maka pelibatan masyarakat menjadi penting untuk dikaji dalam meningkatkan keberhasilan pertumbuhan cempaka di hutan rakyat. Basis strategi peningkatan kinerja petaninya dilakukan melalui pola agroforestri dengan melihat aspek motivasi, kesempatan dan karakteristik petani (Sumarlan, Sumardjo, Tjitropranoto, \& Gani, 2012). Karakteristik petani menjadi penting diteliti untuk meminimalkan kegagalan pembangunan kehutanan akibat kurangnya pemahaman tentang hakekat kehidupan petani sebagai pelaku pembangunan.

Tujuan penelitian ini adalah untuk mempelajari hubungan antara karakteristik internal petani (pengetahuan, sikap dan perilaku) dengan keberhasilan tumbuh cempaka pada pola hutan rakyat di Desa Ginanjar, Kecamatan Ciambar, Kabupaten Sukabumi. Hasil penelitian ini diharapkan dapat menjadi acuan pembinaan petani cempaka di Desa Ginanjar.

\section{METODOLOGI}

\section{A. Tempat Penelitian}

Penelitian dilakukan di hutan rakyat Desa Ginanjar, Kecamatan Ciambar, Sukabumi yang dilakukan pada tahun 2012 sampai 2015. Secara geografis lokasi penelitian berada pada koordinat $105^{\circ} 48^{\prime} 53^{\prime \prime}$ Bujur Timur dan 06 $48^{\prime} 51^{\prime \prime}$ Lintang Selatan dengan ketinggian tempat antara 550-750 $\mathrm{m}$ dari permukaan laut (dpl). Tipe iklim B1 menurut klasifikasi Oldeman dengan rata-rata curah hujan $2.781 \mathrm{~mm} /$ tahun.

\section{B. Metode \\ 1. Pengumpulan data}

Pengumpulan data dilakukan melalui wawancara, pengukuran keberhasilan tumbuh dan pertumbuhan tanaman cempaka serta studi literatur. Wawancara terstruktur dilakukan dengan bantuan kuesioner pada 36 responden. Responden merupakan warga Desa Ginanjar yang dipilih secara sengaja. Responden tersebut merupakan petani yang terlibat sejak awal dilakukan sosialisasi sampai dengan merealisasikan penanaman Cempaka dengan pola hutan rakyat. Respon- 
den terbagi dalam dua kelompok yaitu responden penanaman cempaka tahap 1 (tahun tanam 2012) sebanyak 19 responden dan responden penanaman cempaka tahap 2 (tahun tanam 2013) sebanyak 17 responden. Data primer dikelompokkan dalam 2 bagian yaitu: 1) kondisi sosial ekonomi petani dan karakteristik internal petani (pengetahuan, sikap dan perilaku) terhadap penanaman cempaka, 2) keberhasilan tumbuh dan pertumbuhan tanaman cempaka sampai umur dua tahun. Pengumpulan data kondisi sosial ekonomi petani dilakukan dengan mengumpulkan data umur, tingkat pendidikan, lama berusaha tani dan luas lahan garapan. Sedangkan pengumpulan data karakteristik internal petani meliputi pengetahuan, sikap dan perilaku petani. Komponen pengetahuan mengungkapkan pengetahuan petani terhadap jenis dan nilai ekonomi cempaka. Komponen sikap menggambarkan kesiapan dan kesediaan petani dalam menggembangkan tanaman cempaka. Komponen perilaku menggambarkan tindakan nyata dari individu dalam budidaya cempaka. Ketiga komponen tersebut dikategorikan menjadi tiga yaitu: baik, sedang dan kurang sesuai dengan karakteristik pada Tabel 1 . Pengukuran keberhasilan tumbuh dan pertumbuhan tanaman cempaka sampai umur dua tahun dilakukan dengan cara sensus (pengukuran 100\%) secara berkala dengan interval 6 bulan. Data pengukuran meliputi persen tumbuh, tinggi tanaman dan diameter batang. Tinggi tanaman diukur dari pangkal batang sampai dengan ujung titik tumbuh batang utama. Diameter batang diukur $5 \mathrm{~cm}$ dari permukaan tanah. Data sekunder meliputi keadaan umum hutan rakyat di Desa
Ginanjar Kabupaten Sukabumi diperoleh dari data statistik Kecamatan Ciambar dan berbagai laporan terkait.

\section{Analisis data}

Hasil pengumpulan data primer selanjutnya dianalisis berdasarkan 3 kategori yaitu: baik, sedang dan kurang. Ketiga kategori tersebut, menggambarkan karakteristik internal petani dan keberhasilan tumbuh cempaka (Tabel. 1).

Selanjutnya dilakukan uji korelasi Pearson untuk mengetahui hubungan antara karakteristik internal petani (tingkat pengetahuan, sikap dan perilaku) dengan keberhasilan tumbuh tanaman cempaka. Dasar pengambilan keputusan dalam uji korelasi Pearson adalah jika nilai siginfikan $<0,05$ berarti terdapat hubungan nyata dan jika nilai siginfikan $>0,05$ hubungannya tidak nyata.

Kriteria tingkat hubungan (koefisien korelasi) antar variabel berkisar antara 0 sampai \pm 1 ; tanda "+" adalah positif dan "_" adalah negatif. Kedua variabel bebas dan tak bebas bisa berhubungan dengan salah satu dari tiga cara berikut:

1. Hubungan positif. Artinya, semakin baik karakteristik internal petani maka, semakin tinggi keberhasilan pertumbuhan cempaka.

2. Tidak ada hubungan. Artinya, karakteristik internal petani dan keberhasilan tumbuh cempaka tidak saling berhubungan.

3. Hubungan negatif. Artinya, semakin baik karakteristik internal petani maka, semakin rendah keberhasilan pertumbuhan cempaka. 
Tabel (Table) 1. Pembedaan petani berdasarkan karakteristik internal dan pertumbuhan cempaka (Farmer differentiation based on his internal characteristics and the growth of cempaka)

\begin{tabular}{|c|c|c|c|c|}
\hline \multirow[b]{2}{*}{ Kategori (Classification) } & \multicolumn{4}{|c|}{ Parameter (Parameters) } \\
\hline & $\begin{array}{l}\text { Pengetahuan } \\
\text { terhadap jenis } \\
\text { cempaka } \\
(\text { Knowledge }) \\
\end{array}$ & $\begin{array}{l}\text { Sikap dalam } \\
\text { membudidaya } \\
\text { cempaka } \\
(\text { Attitude) }\end{array}$ & $\begin{array}{l}\text { Perilaku dalam } \\
\text { membudidaya } \\
\text { cempaka } \\
\text { (Behaviour) }\end{array}$ & $\begin{array}{l}\text { Persen tumbuh } \\
\text { cempaka } \\
\text { (Survival of } \\
\text { cempaka) }\end{array}$ \\
\hline Baik (Good) & $\begin{array}{l}\text { - Tahu jenis } \\
\text { (Recognize the } \\
\text { species) } \\
\text { - Tahu nilai } \\
\text { ekonomis } \\
\text { (Know its } \\
\text { economic value) }\end{array}$ & $\begin{array}{l}\text { Menanam dengan } \\
\text { inisiatif sendiri } \\
\text { (Planting by self } \\
\text { willingness) }\end{array}$ & $\begin{array}{l}\text { Pemeliharaan intensif } \\
\text { (High intensity } \\
\text { weeding) } \\
\text { ( } 2 \text { bulan sekali) } \\
\text { (Every } 2 \text { months) }\end{array}$ & $\begin{array}{l}\text { Persen tumbuh } \\
>80 \% \text { (Survival } \\
>80 \%)\end{array}$ \\
\hline Sedang (Fair) & $\begin{array}{l}\text { - Tidak tahu } \\
\text { jenis } \\
\text { (Unrecognize } \\
\text { the species) } \\
\text { - Tahu nilai } \\
\text { ekonomis } \\
\text { (Know its } \\
\text { economic value) }\end{array}$ & $\begin{array}{l}\text { Menanam dengan } \\
\text { insentif \& bibit } \\
\text { (Planting by } \\
\text { insentive and } \\
\text { free seedling) }\end{array}$ & $\begin{array}{l}\text { Pemeliharaan rendah } \\
\text { (Low intensity } \\
\text { weeding) } \\
\text { ( } 6 \text { bulan sekali) } \\
\text { (Every } 6 \text { months) }\end{array}$ & $\begin{array}{l}\text { Persen tumbuh } \\
50-79 \% \\
\text { (Survival 50- } \\
79 \%)\end{array}$ \\
\hline Kurang (Poor) & $\begin{array}{l}\text { - Tidak tahu jenis } \\
\text { (Unrecognize } \\
\text { the species) } \\
\text { - Tidak tahu nilai } \\
\text { ekonomis (Not } \\
\text { knowing its } \\
\text { economic value) }\end{array}$ & $\begin{array}{l}\text { Menanam ikut- } \\
\text { ikutan karena } \\
\text { mendapat } \\
\text { insentif } \\
\text { (Follower) }\end{array}$ & $\begin{array}{l}\text { Tidak dipelihara } \\
\text { (No weeding) }\end{array}$ & $\begin{array}{l}\text { Persen tumbuh } \\
<49 \% \\
(\text { Survival } \\
<49 \%)\end{array}$ \\
\hline
\end{tabular}

Menurut Sugiyono (2007) kriteria untuk memberikan interpretasi koefisien korelasi adalah:

1. 0 sampai 0,19 artinya hubungan sangat rendah.

2. 0,20 sampai 0,39 artinya hubungan rendah.

3. 0,40 sampai 0,59 artinya sedang.

4. 0,60 sampai 0,79 artinya kuat.

5. $0,80-1$ artinya sangat kuat.

Hasil analisis data primer yang diperoleh selanjutnya dilakukan interpretasi. Data sekunder yang telah diperoleh selanjutnya digunakan untuk melengkapi, mendukung dan menguatkan data primer. Analisis paling akhir yang menjadi bagian penting dari penelitian ini adalah melakukan tindakan pemaknaan atas analisis deskripsi dan analisis kecenderungan-kecenderungan yang nampak pada realitas karakteristik internal petani.

\section{GAMBARAN UMUM POTENSI LAHAN KERING DESA GINANJAR}

Desa Ginanjar merupakan salah satu dari tujuh desa yang ada di wilayah Kecamatan Ciambar, Kabupaten Sukabumi. Desa Ginanjar memiliki empat dusun yaitu Dusun Cikatomas, Pasir Hantap, Awilega dan Tugu Jaya. Luas lahan kering di Desa Ginanjar 1.410,30 ha. Lahan tersebut telah terbagi dalam peruntukannya yaitu (1) lahan tegalan/ladang 221,5 ha $(15,7 \%)$, (2) pemukiman 182,3 ha $(12,9 \%)$, (3) 
kehutanan 1.000 ha $(70,9 \%)$, (4) lain lain 6,5 ha $(0,5 \%)$. Potensi peruntukan lahan kehutanan terbesar yaitu $70,9 \%$ pada umumnya digunakan untuk sumber hijauan makanan ternak (HMT) domba/kambing dan sapi yang sedang berkembang di wilayah tersebut. Jenis tanaman kehutanan lainnya seperti mahoni (Swietenia mahagoni L. Jack), kayu afrika (Maesopsis eminii Engl), gmelina (Gmelina arborea Roxb.), jabon putih (Anthocephalus sp.), jati (Tectona grandis L.), suren (Toona sureni Merr.), sengon (Paraserianthes falcataria (L.) Nielsen) sudah ditanam pada lahan kering dengan pola tanam campuran bersama dengan tanaman palawija. Tanaman sengon, suren dan jabon putih merupakan jenis yang paling banyak dibudidayakan. Untuk mendukung ketersediaan bibit bagi berkembangnya hutan rakyat di wilayah ini telah dibangun kebun bibit rakyat (KBR) dari jenis sengon, jabon putih, dan gmelina (BP4K Kecamatan Ciambar, 2012).

Desa Ginanjar didominasi oleh topografi bergelombang (45\%), berbukit $(30 \%)$ dan datar $(25 \%)$ dengan jenis tanah Latosol Coklat dan rata $\mathrm{pH}$ 5-6. Wilayah dengan topografi bergelombang dan berbukit berpotensi untuk pengembangan hutan rakyat khususnya jenis cempaka. Secara umum areal ini sangat rentan jika ditanami tanaman pangan secara monokultur. Kerentanan ini disebabkan Kabupaten Sukabumi merupakan salah satu wilayah yang sering mengalami bencana longsor. Hendriarianti (2010) menyebutkan terdapat enam faktor utama dari aspek sosial ekonomi yang secara langsung atau tidak langsung menjadi penyebab utama menurunnya kualitas lingkungan biofisik melalui proses perusakan lingkungan hutan (deforestasi), yaitu: (1) tingginya populasi penduduk, (2) kurang tepatnya tataguna lahan, (3) tingginya perdagangan kayu, (4) pembangunan infrastruktur yang mengakibatkan tingginya konversi hutan, (5) lemahnya penegakan hukum, serta (6) rendahnya pengetahuan lingkungan. Faktor-faktor tersebut selanjutnya mempercepat terjadinya deforestasi yang secara langsung dapat menyebabkan tanah longsor, erosi tanah, sedimentasi, penurunan kualitas lahan, dan terbentuknya lahan tandus (Hendriarianti, 2010). Berdasarkan aspek lingkungan, faktor yang berpengaruh terhadap kejadian longsor adalah curah hujan, lereng, jenis tanah, litologi, penggunaan, dan penutupan lahan. Kedua aspek tersebut selanjutnya menjadi perhatian penting dalam mengelola lahan di wilayah Kecamatan Ciambar khususnya dan Kabupaten Sukabumi pada umumnya. Upaya rehabilitasi hutan dan lahan pada areal yang memiliki topografi dengan lereng yang curam menjadi keharusan. Upaya ini diharapkan mampu berfungsi sebagai konservasi tanah dan air serta sumber pendapatan petani.

\section{HASIL DAN PEMBAHASAN}

\section{A. Hasil \\ 1. Kondisi sosial ekonomi petani hutan rakyat cempaka}

Petani hutan rakyat cempaka yang dimaksud dalam pembahasan ini merupakan penduduk asli Desa Ginanjar, Kecamatan Ciambar, Kabupaten Sukabumi. Petani tersebut merupakan kepala keluarga yang terlibat dalam penanaman cempaka dengan pola hutan rakyat yang difasilitasi oleh Pusat Penelitian dan Pengembangan Hutan, Bogor. Kondisi sosial ekonomi petani hutan rakyat cempaka disajikan dalam Tabel 2.

Berdasarkan data Tabel 2 diketahui bahwa perbedaan kondisi sosial ekonomi petani tahap 1 dan 2 terutama pada sebaran umur. Petani tahap 1 merupakan petani yang sebagian besar berusia lanjut (51-60 tahun) sedangkan petani tahap 2 didominasi oleh petani yang berusia produktif (41-50 tahun). Sementara itu 
sebagian besar petani berpendidikan setingkat $\mathrm{SD}$, bermata pencaharian utama sebagai petani, lama berusaha tani $\geq 20$ tahun dan memiliki lahan $\leq 1$ ha.

\section{Karakteristik internal petani cempaka}

Dalam upaya meningkatkan keberhasilan pertumbuhan cempaka di hutan rakyat, maka penting untuk mengetahui karakteristik internal petani (pengetahuan, sikap dan perilaku petani). Kondisi perbedaan ketiga komponen tersebut dapat dijadikan dasar bagi pelaksana kegiatan untuk meningkatkan respon petani terhadap pembangunan hutan rakyat. Karakteristik internal petani cempaka di hutan rakyat Desa Ginanjar, Kecamatan Ciambar, Kabupaten Sukabumi dapat dilihat pada Tabel 3.

Tabel (Table) 2. Kondisi sosial ekonomi petani hutan rakyat cempaka Desa Ginanjar, Kecamatan Ciambar, Kabupaten Sukabumi (Social economic condition of private forest farmer in Ginanjar Village, Ciambar Sub District, Sukabumi Distrct)

\begin{tabular}{|c|c|c|c|c|c|}
\hline \multirow[b]{2}{*}{$\begin{array}{c}\text { Karakteristik } \\
\text { responden } \\
\text { (Characteristics } \\
\text { of respondent) }\end{array}$} & \multirow[b]{2}{*}{$\begin{array}{c}\text { Klasifikasi } \\
\text { (Classification) }\end{array}$} & \multicolumn{2}{|c|}{ Tahap 1(Phase 1) } & \multicolumn{2}{|c|}{ Tahap 2 (Phase 2) } \\
\hline & & $\begin{array}{c}\text { Jumlah responden } \\
\text { (Number of } \\
\text { respondents) }\end{array}$ & $\begin{array}{c}\text { Persen } \\
\text { (Percent) } \\
\quad(\%)\end{array}$ & $\begin{array}{l}\text { Jumlah } \\
\text { Responden } \\
\text { (Number of } \\
\text { respondents) }\end{array}$ & $\begin{array}{c}\text { Persen } \\
\text { (Percent) } \\
(\%)\end{array}$ \\
\hline \multirow{5}{*}{$\begin{array}{l}\text { Umur (Age old) } \\
\text { (Tahun) } \\
\text { (Year) }\end{array}$} & $20-30$ & 1 & 5,26 & 1 & 5,88 \\
\hline & $31-40$ & 1 & 5,26 & 4 & 23,53 \\
\hline & $41-50$ & 4 & 21,05 & 7 & 41,18 \\
\hline & $51-60$ & 10 & 52,63 & 4 & 23,53 \\
\hline & $>60$ & 3 & 15,79 & 1 & 5,88 \\
\hline \multirow[t]{4}{*}{$\begin{array}{l}\text { Pendidikan } \\
\text { (Education) }\end{array}$} & $\begin{array}{l}\text { Tidak sekolah (Do not } \\
\text { go to school) }\end{array}$ & 0 & 0,00 & 5 & 29,41 \\
\hline & SD (Primary school) & 14 & 82,35 & 9 & 52,94 \\
\hline & $\begin{array}{l}\text { SLTP (Secondary } \\
\text { School) }\end{array}$ & 4 & 23,53 & 1 & 5,88 \\
\hline & SLTA (High school) & 1 & 5,88 & 2 & 11,76 \\
\hline \multirow[t]{2}{*}{$\begin{array}{l}\text { Pekerjaan utama } \\
(\text { Main job })\end{array}$} & $\begin{array}{l}\text { Tani atau Buruh tani } \\
\text { (Farmer or On-farm } \\
\text { labour) }\end{array}$ & 15 & 78,95 & 15 & 88,24 \\
\hline & $\begin{array}{l}\text { Pedagang atau Jasa } \\
\text { lainnya (Trader or } \\
\text { Other service) }\end{array}$ & 4 & 21,05 & 2 & 11,76 \\
\hline \multirow{2}{*}{$\begin{array}{l}\text { Pengalaman } \\
\text { berusaha tani } \\
\text { (Farming } \\
\text { experience) }\end{array}$} & $\leq 20$ tahun & 7 & 38,89 & 8 & 47,06 \\
\hline & $>20$ tahun & 12 & 66,67 & 9 & 52,94 \\
\hline \multirow{3}{*}{$\begin{array}{l}\text { Luas lahan milik } \\
\text { (Size of land } \\
\text { holding) }\end{array}$} & $\leq 1$ ha & 17 & 89,47 & 16 & 94,12 \\
\hline & $>1$ ha & 2 & 10,53 & 1 & 5,88 \\
\hline & Jumlah (Total) & 19 & 100,00 & 17 & 100,00 \\
\hline
\end{tabular}


Tabel (Table) 3. Pengetahuan, sikap dan perilaku petani dalam budidaya tanaman cempaka (Knowledge, attitudes and behavior of farmers in the cultivation of cempaka)

\begin{tabular}{|c|c|c|c|c|c|c|c|c|c|c|}
\hline \multicolumn{2}{|c|}{$\begin{array}{l}\text { Responden } \\
\text { (Respondent) }\end{array}$} & \multicolumn{3}{|c|}{$\begin{array}{l}\text { Pengetahuan } \\
\text { (Knowledge) }\end{array}$} & \multicolumn{3}{|c|}{ Sikap (Attitudes) } & \multicolumn{3}{|c|}{ Perilaku (Behavior) } \\
\hline & & B & $\mathrm{S}$ & K & B & S & K & B & S & K \\
\hline \multirow{2}{*}{$\begin{array}{l}\text { Tahap 1 } \\
\text { (Phase 1) }\end{array}$} & $\mathrm{N}$ & 11 & 6 & 2 & 11 & 5 & 3 & 1 & 15 & 3 \\
\hline & $\%$ & 57,89 & 31,58 & 10,53 & 57,89 & 26,32 & 15,79 & 5,26 & 78,95 & 15,79 \\
\hline \multirow{2}{*}{$\begin{array}{l}\text { Tahap 2 } \\
\text { (Phase 2) }\end{array}$} & $\mathrm{N}$ & 5 & 5 & 7 & 10 & 7 & 0 & 10 & 4 & 3 \\
\hline & $\%$ & 29,41 & 29,41 & 41,18 & 58,82 & 41,18 & 0,00 & 58,82 & 23,53 & 17,65 \\
\hline
\end{tabular}

Keterangan (Remarks): B = Baik (Good), S = Sedang (Fair), K = Kurang (Poor), N = Jumlah responden (Number of respondents)

Secara keseluruhan petani yang terlibat dalam kegiatan penanaman cempaka memiliki latar belakang tingkat pengetahuan, sikap dan perilaku yang berbeda. Petani tahap 1 didominasi ketegori pengetahuan dan sikap yang baik, serta perilaku ketegori sedang. Petani tahap 2 didominasi pengetahuan yang kurang, tetapi sikap dan perilaku termasuk kategori baik. Walaupun kelompok tani tahap 1 dan tahap 2 berbeda karakteristiknya ternyata menghasilkan tingkat keberhasilan tumbuh cempaka yang tinggi.

Keberhasilan tumbuh dan pertumbuhan tanaman cempaka merupa-kan gambaran hasil interaksi petani dan tanaman cempaka. Pertumbuhan cempaka tahap 1 dan tahap 2 sampai dengan umur dua tahun dapat dilihat pada Tabel 4.

Tabel (Table) 4. Pertumbuhan cempaka pada hutan rakyat Desa Ginanjar Kecamatan Ciambar, Sukabumi (Growth of Cempaka on private forests in Ginanjar Village, Ciambar Sub District, Sukabumi District)

\begin{tabular}{|c|c|c|c|c|}
\hline Variabel (Variable) & \multicolumn{2}{|c|}{ Tahap 1 (Phase 1) } & \multicolumn{2}{|c|}{ Tahap 2 (Phase 2) } \\
\hline & $\begin{array}{c}\text { Umur } 1 \text { tahun } \\
\text { (1 Year old }) \\
*\end{array}$ & $\begin{array}{c}\text { Umur } 2 \text { tahun } \\
(2 \text { Year old }) \\
*\end{array}$ & $\begin{array}{c}\text { Umur } 1 \text { tahun } \\
\text { (1 Year old }) \\
*\end{array}$ & $\begin{array}{l}\text { Umur } 2 \text { tahun } \\
\text { (2 Year old) }\end{array}$ \\
\hline $\begin{array}{l}\text { Rerata tinggi } \\
(\text { Average height })(\mathrm{cm})\end{array}$ & 85,0 & 234,0 & 154,0 & 286,0 \\
\hline $\begin{array}{l}\text { Rerata diamater } \\
(\text { Average diameter }) \\
(\mathrm{cm})\end{array}$ & 1,3 & 3,9 & 2,3 & 4,4 \\
\hline $\begin{array}{l}\text { Rerata diameter } \\
\text { setinggi dada } \\
\text { (Average diameter at } \\
\text { breast height })(\mathrm{cm})\end{array}$ & - & 2,4 & - & 2,7 \\
\hline $\begin{array}{l}\text { Rerata persen hidup } \\
\text { (Average Survival) } \\
(\%)\end{array}$ & 71 & 70 & 85 & 83 \\
\hline
\end{tabular}


Secara umum keberhasilan tumbuh tanaman cempaka sampai dengan umur 2 tahun pada tahap 1 berada pada kategori sedang $(>59 \%)$ dan tahap 2 kategori tinggi (> 80\%). Kondisi ini menunjukkan bahwa tanaman cempaka dapat beradaptasi dengan baik di hutan rakyat Desa Ginanjar, Kecamatan Ciambar.

Adanya faktor-faktor pembatas di dalam keberhasilan pertumbuhan tanaman cempaka, maka dilakukan pengujian hubungan pengetahuan, sikap dan perilaku petani terhadap keberhasilan tumbuh tanaman cempaka. Hubungan tersebut disajikan pada Tabel 5 dan 6.

Tabel 5 menunjukkan terdapat korelasi antara pengetahuan dan sikap dengan keberhasilan tumbuh cempaka. Korelasi positif ditunjukkan oleh sikap petani dengan nilai hubungan sedang $(0,59)$. Korelasi negatif ditunjukkan oleh nilai hubungan sedang $(-0,570)$. Tabel 6 menunjukkan bahwa tidak ada korelasi antara pengetahuan dan sikap petani tahap 2 terhadap keberhasilan tumbuh cempaka. Korelasi positif terlihat antara perilaku petani tahap 2 terhadap tingkat keberhasilan tumbuh cempaka dengan nilai hubungan kuat $(0,687)$. Kondisi ini menunjukkan bahwa semakin baik perilaku petani akan meningkatkan keberhasilan tumbuh cempaka.

Tabel (Table) 5. Hubungan karakteristik internal petani dengan keberhasilan tumbuh cempaka pada hutan rakyat tahap 1 (Correlation between farmer's internal characteristics and growth of cempaka on private forest at phase 1)

\begin{tabular}{|c|c|c|c|c|}
\hline & $\begin{array}{l}\text { Pengetahuan } \\
\text { (Knowledge) }\end{array}$ & $\begin{array}{l}\text { Sikap } \\
\text { (Attitudes) }\end{array}$ & $\begin{array}{l}\text { Perilaku } \\
\text { (Behavior) }\end{array}$ & $\begin{array}{c}\text { Persen } \\
\text { tumbuh } \\
\text { (Survival) }\end{array}$ \\
\hline Pengetahuan (Knowledge) & $1^{\text {tn }}$ & $-0,393^{\mathrm{tn}}$ & $-0,183^{\text {tn }}$ & $-0,570^{*}$ \\
\hline Sikap (Attitudes) & $-0,393^{\text {tn }}$ & $1^{\text {tn }}$ & $0,133^{\text {tn }}$ & $0,590^{* *}$ \\
\hline Perilaku (Behavior) & $-0,183^{\text {tn }}$ & $0,133^{\text {tn }}$ & $1^{\text {tn }}$ & $-0,294^{\mathrm{tn}}$ \\
\hline Persen tumbuh (Survival) & $-0,570^{*}$ & $0,590^{* *}$ & $-0,294^{\mathrm{tn}}$ & $1^{\text {tn }}$ \\
\hline
\end{tabular}

Tabel (Table) 6. Hubungan karakteristik internal petani dengan keberhasilan tumbuh cempaka pada hutan rakyat tahap 2 (Correlation between farmer's internal characteristics and growth of cempaka on private forest at phase 2)

\begin{tabular}{|c|c|c|c|c|}
\hline & $\begin{array}{l}\text { Pengetahuan } \\
\text { (Knowledge) }\end{array}$ & $\begin{array}{c}\text { Sikap } \\
\text { (Attitudes) }\end{array}$ & $\begin{array}{l}\text { Perilaku } \\
\text { (Behavior) }\end{array}$ & $\begin{array}{l}\text { Persen } \\
\text { tumbuh } \\
\text { (Survival) }\end{array}$ \\
\hline Pengetahuan (Knowledge) & $1^{\text {th }}$ & $0,097^{\text {tn }}$ & $-0,272^{\mathrm{tn}}$ & $-0,060^{\text {tn }}$ \\
\hline Sikap (Attitudes) & $0,097^{\mathrm{tn}}$ & $1^{\text {tn }}$ & $-0,018^{\text {tn }}$ & $0,001^{\text {tn }}$ \\
\hline Perilaku (Behavior) & $-0,272^{\text {tn }}$ & $-0,018^{\text {tn }}$ & $1^{\text {tn }}$ & $0,687^{* *}$ \\
\hline Persen tumbuh (Growth) & $-0,060^{\text {tn }}$ & $0,001^{\text {tn }}$ & $0,687^{* *}$ & $1^{\text {tn }}$ \\
\hline
\end{tabular}




\section{B. Pembahasan}

Petani hutan rakyat cempaka di Desa Ginanjar memiliki kondisi sosial ekonomi berupa tingkat pendidikan, pekerjaan utama, lama berusaha tani dan luas lahan yang homogen. Homogenitas petani tersebut disebabkan oleh tingkat pendidikan yang rendah sehingga pada umumnya petani tidak memiliki keahlian untuk melakukan usaha sampingan dan sejak muda terus bekerja di sektor pertanian. Homogenitas petani dapat menjadi modal besar bagi penggalangan masa untuk kegiatan pengembangan hutan rakyat, karena karakteristik yang homogen lebih mudah dibina (Achmad, B., Hasanu, S., Diniyati, D., \& Widyaningsih, 2012). Namun demikian terdapat perbedaan pada karakteristik internal petani.

Berdasarkan hasil analisis menunjukkan bahwa petani tahap 1 didominasi oleh sebagian besar petani berusia tua $(57,89 \%)$ dan memiliki pengetahuan yang baik terhadap jenis cempaka. Karaktersitik petani tersebut ternyata mampu mengggambarkan ciri fisik tanaman cempaka dan aroma yang dihasilkan dari bunga cempaka. Aroma cempaka dipercaya dapat menarik perhatian konsumen jika bangunan warung terbuat dari kayu cempaka. Pengetahuan tidak saja terhadap jenis tanaman, tetapi juga manfaat dan nilai ekonomi tanaman cempaka. Petani pernah melihat keberadaan tanaman cempaka di wilayah Desa Ginanjar sekitar sepuluh tahun yang lalu. Namun saat ini cempaka sudah tidak ditemui di Desa Ginanjar, Kecamatan Ciambar, Kabupaten Sukabumi. Berbeda dengan petani tahap 2 yang didominasi oleh petani berumur muda. Petani tersebut memiliki pengetahuan terhadap cempaka dengan kategori kurang (41,18\%). Sebagian besar petani tidak mengetahui jenis cempaka dan nilai ekonomisnya. Hal ini menunjukkan bahwa semakin tua umur seseorang, maka semakin banyak yang diketahui sebagai akibat berkembangnya daya tangkap dan pola pikirnya. Sebaiknya, semakin muda umur seseorang semakin sedikit hal yang diketahuinya tentang komoditas cempaka.

Sikap petani terhadap keterlibatan penanaman cempaka menunjukkan bahwa petani tahap 1 dan 2 memiliki sikap yang baik sebesar $57,89 \%$ dan $58,82 \%$. Namun demikian $15,79 \%$ petani tahap 1 memiliki sikap hanya menanam dengan ikut-ikutan, sedangkan petani tahap 2 walaupun sebagian besar belum mengenal tanaman cempaka namun tidak terdapat petani yang hanya ikut-ikutan dalam menanam cempaka. Jumlah petani yang memiliki sikap baik sangat potensial dalam merealisasikan penanaman karena mempunyai keinginan sendiri, serta kesadaran yang tinggi untuk melakukan penanaman. Sedangkan petani lainnya melakukan penanaman hanya karena ingin mendapatkan bibit gratis dan insentif biaya tanam dan pupuk.

Perilaku petani tahap 1 sebagian besar $(78,95 \%)$ masuk dalam kategori sedang artinya petani melakukan penanaman dan pemeliharaan dengan intensitas rendah (6 bulan sekali membersihkan gulma). Hal ini disebabkan karena sebelumnya petani tidak terbiasa melakukan budidaya tanaman berkayu. Jenis tanaman yang umum dibudidayakan adalah padi dan palawija. Petani menganggap bahwa tanaman kayu tidak membutuhkan perawatan rutin sebagimana tanaman palawija. Petani tahap 2 sebagian besar berperilaku baik yaitu melakukan penanaman cempaka dengan intensitas pemeliharaan yang tinggi ( 2 bulan sekali membersihkan gulma). Kondisi ini disebabkan karena petani tahap 2 telah lama mengusahakan tanaman kayu dan mengetahui pentingnya pemeliharaan pada awal pertumbuhunnya serta memiliki kesadaran tinggi dalam mengembangkan cempaka di hutan rakyat. 
Kelompok tani di Desa Ginanjar memiliki tingkat pengetahuan, sikap dan perilaku yang berbeda. Namun perbedaan karakteristik tersebut telah menghasilkan tingkat keberhasilan tumbuh cempaka yang tinggi. Secara umum keberhasilan tumbuh tanaman cempaka sampai dengan umur dua tahun pada tahap 1 berada pada kategori sedang $(>59 \%)$ dan tahap 2 kategori tinggi $(>80 \%)$. Kondisi ini menunjukkan bahwa tanaman cempaka dapat beradaptasi dengan baik di hutan rakyat Desa Ginanjar, Kecamatan Ciambar. Murniati \& Octavia (2013) melaporkan uji empat provenan campaka yang dilakukan di hutan penelitian Pasir Hantap Kecamatan Ciambar menunjukkan keberhasilan tumbuh ratarata mencapai $82,1 \%$ pada umur satu tahun dan keberhasilan tumbuh tertinggi ditunjukan oleh provenan asal Lahat mencapai $90,6 \%$. Octavia \& Murniati (2016) menyebutkan persen tumbuh yang dihasilkan pada penanaman tahap 1 pada umur dua tahun (70\%) dan tahap 2 pada umur satu tahun (85\%) menunjukkan bahwa cempaka memiliki toleransi dan adaptasi tumbuh yang cukup baik di wilayah Desa Ginanjar, Kecamatan Ciambar. Hal ini didukung oleh kualitas benih cempaka. Asal benih cempaka yang di tanam pada hutan rakyat Desa Ginanjar, Kecamatan Ciambar diperoleh dari tegakan benih teridentifikasi asal Kabupaten Lahat yang telah berumur 30 tahun dengan batang lurus dan tinggi bebas cabang relatif tinggi $\geq 10 \mathrm{~m}$ (Murniati \& Octavia, 2013). Jika dibandingkan keberhasilan tumbuh cempaka provenan Lahat di hutan penelitian Pasir Hantap dengan di hutan rakyat Desa Ginanjar, maka terlihat penurunan persen tumbuh pada hutan rakyat. Selanjutnnya persen tumbuh tanaman cempaka pada lahan hutan rakyat tahap 2 lebih tinggi dibandingkan tahap 1. Kondisi ini menunjukkan faktor biofisik lahan dan asal benih tidak menjadi faktor pembatas pertumbuhan cempaka di Kecamatan Ginanjar. Oleh karena itu, faktor petani selaku pelaku dalam budidaya cempaka diduga memiliki hubungan terhadap keberhasilan pertumbuhan cempaka.

Petani sebagai pelaku budidaya memiliki pengetahuan tentang suatu obyek dengan dua aspek yaitu aspek positif dan aspek negatif. Kedua aspek ini yang akan menentukan sikap seseorang. Semakin banyak aspek positif dari obyek yang diketahui, maka akan menimbulkan sikap makin positif terhadap obyek tersebut. Sikap merupakan kesiapan atau kesediaan dalam bertindak, dan bukan pelaksanaan motif tertentu. Perilaku merupakan suatu aksi dan reaksi suatu individu terhadap lingkungannya.

Tabel 5 menunjukkan terdapat korelasi negatif antara pengetahuan petani tahap 1 dan keberhasilan tumbuh cempaka dengan nilai hubungan sedang $(-0,570)$. Kondisi ini menunjukkan meningkatnya pengetahuan empiris petani tidak meningkatkan keberhasilan tumbuh cempaka. Petani tahap 1 mengenal cempaka melalui pengalaman yaitu melihat langsung di alam dan mengetahui nilai ekonomi kayu cempaka. Berdasarkan kondisi tersebut maka, tingkat pengetahuan petani tahap 1 berada pada tingkatan paling bawah yang dikenal dengan "Tahu (Know)". Tingkatan pengetahuan ini diartikan sebagai kondisi dimana petani dapat mengingat sesuatu benda yang telah dipelajarinya dengan cara menyebutkan, menguraikan, mengidentifikasi maupun menyatakan. Tingkat pengetahuan petani belum berada pada tingkat pengetahuan berikutnya yaitu memahami dan aplikasi. Pada tingkatan memahami dan aplikasi petani telah mampu melakukan sikap dan perilaku pada hal-hal yang telah dipahaminya. Sementara itu, pengetahuan budidaya belum pernah diperoleh petani baik secara formal maupun informal. Berdasarkan kondisi tersebut petani belum mampu mengunakan daya pikirnya 
untuk melakukan budidaya intensif pada awal pertumbuhan cempaka. Keterbatasan tingkat pengetahuan dalam budidaya mengakibatkan rendahnya keberhasilan tumbuh cempaka.

Untuk meningkatkan keberhasilan tumbuh cempaka perlu dilakukan peningkatan pengetahuan petani ke tahap tingkatan berikutnya. Peningkatan pengetahuan dapat dilakukan secara formal melalui proses pembelajaran atau pelatihan budidaya yang dilakukan terhadap petani hutan rakyat. Wawan \& Dewi (2011) menyatakan bahwa proses belajar merupakan pertemuan antara faktor keturunan dan faktor lingkungan untuk mempengaruhi seseorang. Proses belajar seringkali tidak terjadi pada petani akibat kurang memiliki sarana dan sumber pengetahuan secara formal, dan justru mengandalkan pengalaman sebagai sumber pengetahuan (Isaac, Erikson, Quashie-Sam, \& Timmer, 2007).

Sebaliknya sikap petani tahap 1 berkorelasi positif dengan keberhasilan tumbuh cempaka dengan nilai korelasi sedang $(0,590)$. Hal ini menunjukkan bahwa semakin baiknya sikap petani tahap 1 akan meningkatkan keberhasilan tumbuh cempaka. Sikap baik petani tahap 1 didasarkan pada presepsi positif terhadap tanaman cempaka yang mengakibatkan keinginan yang kuat untuk menaman cempaka. Keinginan ini didorong atas kebutuhan ekonomi rumah tangga petani. Dadang (2007) menyebutkan bahwa adanya prospek pasar yang cukup baik merupakan peluang usaha hutan rakyat. Peluang ini secara tidak langsung mampu mendorong sikap petani untuk mengembangkan cempaka dengan kesadaran sendiri, tanpa bantuan bibit ataupun insentif. (Achmad, Hasanu, Diniyati, \& Widyaningsih, 2012) menyebutkan petani di Ciamis mempunyai persepsi positif terhadap manfaat dan cara pengelolaan hutan sehingga berkontribusi besar pada kelestarian hutan dan pendapatan petani.
Perilaku petani merupakan tindakan nyata petani terhadap tanaman cempaka di hutan rakyat. Perilaku dapat dipengaruhi oleh faktor genetik atau keturunan dan faktor lingkungan (Wawan \& Dewi, 2011). Secara genetik perilaku petani yang baik diduga disebabkan oleh umur petani, sedangkan faktor lingkungan diduga disebabkan oleh peran sumberdaya dan orientasi ekonomi. Joshi \& Arano (2009) mengungkapkan bahwa umur, pendidikan, pendapatan dan pekerjaan berpengaruh pada keputusan dalam menanam di lahan milik. Hal yang sama diungkapkan oleh (McGinity, Swisher, \& Alavalapati, 2008) bahwa umur dan pendapatan berpengaruh signifikan terhadap adopsi dalam menerapkan agroforestri. Peran sumberdaya meliputi berbagai ketersediaan materi, waktu, ketrampilan dan fasilitas lainnnya, sedangkan orientasi ekonomi merupakan barang/jasa yang diperoleh akibat perilaku yang dilakukan. Premono \& Lestari (2014) menyebutkan bahwa karakteristik umur, jumlah anggota yang bekerja dan pendapatan merupakan faktor yang mempengaruhi keputusan dan minat petani dalam menanam. Petani tahap 2 sebagian besar berumur produktif 41-50 tahun dan merupakan kelompok pemilik lahan $\leq 1$ ha. Kondisi fisik yang masih produktif dan memiliki lahan yang relatif kecil, maka perilaku interaksi petani terhadap lahan cukup baik.

Keberhasilan pembangunan dan pengembangan hutan rakyat tergantung pada interaksi petani dan teknik silvikultur yang dilakukan oleh petani. Jika intensitas interaksi petani terhadap hutan rakyat tinggi, maka produktifitas lahan meningkat dan produksi kayu terpenuhi secara berkelanjutan sehingga kesejahteraan petani meningkat. Selain interaksi petani terhadap hutan Martin \& Galle (2009) mengungkapkan bahwa ukuran luas lahan berhubungan dengan motivasi petani dalam mendukung kegiatan penanaman pohon di hutan rakyat. 
Sedangkan pendidikan yang rendah akan mempengaruhi konsistensi dalam pelaksanaan kegiatan.

Petani tahap 2 lebih sering melakukan aktifitas pembersihan lahan yang berdampak pada rendahnya persen kematian tanaman. Tanaman muda cenderung membutuhkan pemeliharaan yang intensif untuk membersihkan tumbuhan pengganggu seperti liana yang sering melilit pada batang tanaman cempaka. Interaksi yang tinggi antara petani dan tanaman cempaka didukung oleh sikap petani yang sebagian besar menanam dengan kesadaran untuk memperoleh pendapatan dan tidak hanya sekedar mengharapkan insentif maupun ikut-ikutan. Hal ini menunjukkan bahwa persepsi dan motivasi memiliki hubungan yang erat dengan intensitas pengelolaan hutan. Walaupun tingkat pengetahuan petani tahap 2 terhadap jenis cempaka kurang, namun sikap dan perilaku petani telah mendorong intensitas petani dalam memelihara cempaka. Hal ini sejalan dengan Waluyo, Ulya, \& Martin (2010) yang menyatakan bahwa sebagian besar responden mempunyai perilaku positif terhadap program pengembangan hutan rakyat meskipun mereka kurang berpengalaman dalam menanam pohon.

Semakin intensif mereka berinteraksi, semakin banyak mendapat informasi baru dan berbagai alternatif untuk meningkatkan kualitas usahatani mereka. Selain itu dengan kecenderungan umur petani tahap 2 yang masih muda mampu memahami penjelasan singkat yang diberikan sebagai arahan budidaya cempaka. Winata, \& Yuliana (2012) menyatakan bahwa umur petani hutan berpengaruh signifikan terhadap keikutsertaan petani dalam perencanaan dan evaluasi program PHBM (Pengelolaan Hutan Bersama Masyarakat). Sementara luas lahan garapan yang dimiliki oleh petani berpengaruh negatif secara signifikan terhadap kegiatan petani hutan dalam menanami lahan dengan tanaman semusim. Semakin luas lahan yang dimiliki oleh petani hutan, maka tingkat penanaman tanam semusim semakin rendah. Oleh karena itu, tingkat persen tumbuh $85 \%$ dapat dikatakan petani tahap 2 sangat berpotensi mengembangkan cempaka di hutan rakyat. Potensi petani tersebut dapat ditingkatkan melalui optimalisasi pemanfaatan lahan dan memperkuat kelembagaan petani dalam menghadapi pasar kayu cempaka dalam skala yang lebih luas. Hal ini sejalan dengan (Rizal, Nurhaedah, \& Hapsari, 2012) yang meyatakan bahwa lahan hutan rakyat, status hak kepemilikan lahan, dan kelembagaan masyarakat merupakan pendorong dalam strategi optimalisasi pemanfaatan lahan di bawah tegakan hutan rakyat.

\section{KESIMPULAN DAN SARAN}

\section{A. Kesimpulan}

Terdapat hubungan yang berpengaruh nyata antara karakteristik internal petani (pengetahuan, sikap dan perilaku) dengan keberhasilan tumbuh cempaka (Michelia champaca L.). Hubungan positif ditunjukkan oleh sikap dan perilaku, dimana semakin baik sikap dan perilaku, maka semakin tinggi keberhasilan tumbuh cempaka. Hubungan paling kuat ditunjukkan oleh karakteristik perilaku, dimana keberhasilan pertumbuhan cempaka sangat dipengaruhi oleh aktifitas petani dalam pemeliharaan tanaman.

\section{B. Saran}

Untuk meningkatkan keberhasilan pertumbuhan cempaka diperlukan proses pembinaan petani dengan cara yang berbeda. Pembinaan petani dengan kategori pengetahuan baik, sikap baik dan perilaku sedang dapat dilakukan dengan meningkatkan pengetahuan petani secara formal. Pengetahuan dapat berupa teknik 
budidaya maupun ekonomi dan pasar cempaka. Sebaliknya pembinaan petani kategori pengetahuan kurang, sikap baik dan perilaku baik dilakukan dengan mengoptimalkan lahan dan memperkuat kelembagaan petani dalam menghadapi pasar kayu cempaka dalam skala yang lebih luas.

\section{UCAPAN TERIMAKASIH}

Penghargaan yang tinggi kami sampaikan kepada Pusat Penelitian dan Pengembangan Hutan $(\mathrm{P} 3 \mathrm{H})$ atas dukungan sumber dana sehingga penelitian ini dapat terlaksana secara berkesinambungan. Ucapan terimakasih disampaikan pula kepada masyarakat Desa Ginanjar Kecamatan Ciambar Kabupaten Sukabumi atas kesediaan dan partisipasinya dalam membangun demplot hutan rakyat cempaka sebagai upaya konservasi ex situ di lahan masyarakat. Ucapan yang sama disampaikan kepada Bapak Jarkasih, Bapak Kusnadi, Bapak Apid Robini dan semua tim penelitian yang secara langsung maupun tak langsung telah membantu dalam pengumpulan dan pengolahan data selama penelitian berlangsung.

\section{DAFTAR PUSTAKA}

Achmad, B., Hasanu, S., Diniyati, D., \& Widyaningsih, T. (2012). Presepsi petani terhadap pengelolaan dan fungsi hutan rakyat di Kabupaten Ciamis. Jurnal Bumi Lestari, 12(1), 123-136.

BP4K (Badan Pelaksana Penyuluh, Pertanian, Perikanan dan Kehutanan), 2012. Laporan program penyuluhan pertanian, perikanan dan kehutanan Kecamatan Ciambar.

Dadang, R. (2007). Peran hutan rakyat dalam perekonomian wilayah Kabupaten Sumedang. Institu Pertanian Bogor.
Fahmi, A.I., Winandi, R., \& Kusnandi, N. (2013). Alokasi sumberdaya kawasan hutan rakyat Kabupaten Sukabumi, Jawa Barat. Pendekatan Multi-Objective programing. Jurnal Agribisnis Indonesia, 1(2), 95-106.

Hendriarianti, E. (2010). Analisis isu deforestasi pada daerah tangkapan air Bendungan Lobak Kabupaten Boolang Mongondow Propinsi Sulawesi Utara. Jurnal Specta, 8(16), 39-52.

Isaac, M.E., Erikson, B.H., Quashie-Sam, S.,\& Timmer, V. (2007). Transfer of knowledge on agroforestry management practices: The structure of farmer advice networks. Ekology and Society, 12(2), 32-42.

Joshi, S., \& Arano, K. (2009). Determinants of private forest management decisions: A study on West Virginia NIPF LandownersNo Title. Forest Policy and Econoics, $11,80-125$.

Martin, E., \& Galle, F.B. (2009). Motivasi dan karakter sosial ekonomi rumah tangga penanam pohon penghasil kayu pertukangan: Kasus tradisi menanam kayu bawang (Disoxylum molliscimum BL) oleh masyarakat Kabupaten Bengkulu Utara, Bengkulu. Jurnal Penelitian Sosial dan Ekonomi Kehutanan, 6(2), 117-134.

McGinity, M.M., Swisher, M.E., \& Alavalapati, J. (2008). Agroforestry adoption and maintenance: SelfEfficacy, attitudes and socioeconomic factors No Title. Agroforestry Systems, 73, 99-108.

Murniati, \& Octavia, D. (2013). Initial growth of four provenances of cempaka (Michelia champaca Linn.) at a genetic conservation plot. Journal of Basic and Applied Scientific Research, 3(6), 267-271. 
Octavia, D., \& Murniati. (2016). Pertumbuhan awal cempaka (Michelias champaca Linn). Pada plot hutan rakyat di Desa Ginanjar, Kecamatan Ciambar, Sukabumi. Prosiding Seminar Nasional Silikultur III. Bogor. 289-295.

Premono, B.T. \& Lestari, S. (2014). Karakteristik petani dan praktek silvikultur Agroforestri kayu bawang (Azadiracta exelca (jack) M. Jacobs) di Kabupaten Bengkulu Tengah. Jurnal Penelitian Hutan Tanaman, 11(3), 185-197.

Rizal, H.B., Nurhaedah, \& Hapsari, E. (2012). Kajian strategi optimalisasi pemanfaatan lahan hutan rakyat di Provinsi Sulawesi Selatan. Jurnal Penelitian Sosial dan Ekonomi Kehutanan, 4, 216-228.

Sugiyono. (2007). Statistik nonparametrik untuk penelitian. Alfabeta. Bandung.

Sumarlan, Sumardjo, Tjitropranoto, \& Gani, D. (2012). Peningkatan kinerja petani sekitar hutan dalam penerapan sistem agroforestri di Pegunungan Kendeng Pati. Jurnal Agro Ekologi, 30(1), 25-39.

Waluyo, E., Ulya, N., \& Martin, E. (2010). Perencanaan sosial dalam rangka pengembangan hutan rakyat di Sumatra Selatan. Jurnal Penelitian Hutan dan Konservasi Alam, 7(3), 271-280.
Irma Yeny, Murniati dan Dona Octavia

Wawan, A., \& Dewi, M. (2011). Teori dan pengukuran pengetahuan, sikap dan perilaku manusia. Nuha Medica. Yogjakarta.

Winata, A., \& Yuliana, E. (2012). Tingkat Partisipasi Petani Hutan dalam Program Pengelolaan Hutan Bersama Masyarakat (PHBM) Perhutani. Jurnal Mimbar, 28(1), 65-76.

Winata, A., \& Yuliana, E. (2014). Potensi tegakan sebagai indikator tingkat keberhasilan pengelolaan hutan bersama masyarakat(PHBM) Perhutani. Jurnal Matematika, Sains, dan Teknologi, 15(2), 106118.

Yulianingtyas, A., Sebayang, H., \& Tyasmoro, S.Y. (2015). Pengaruh komposisi media tanam dan ukuran bibit pada pertumbuhan pembibitan tebu (Saccharum officinarum L.). Jurnal Produksi Tanaman, 3(5), 4557. 